\title{
Intra-uterine experimental infection by Ureaplasma diversum induces TNF- $\alpha$ mediated womb inflammation in mice
}

\author{
JAMILE R. SILVA ${ }^{1}$, LÍCIO F.A.A. FERREIRA ${ }^{1}$, PERCÍLLIA V.S. OLIVEIRA ${ }^{1}$, IVANÉIA V. NUNES ${ }^{1}$, ÍTALO S. \\ PEREIRA $^{1}$, JORGE TIMENETSKY ${ }^{2}$, LUCAS M. MARQUES ${ }^{1}$, TIANA B. FIGUEIREDO ${ }^{1}$ and ROBSON A.A. SILVA ${ }^{1}$ \\ ${ }^{1}$ Laboratório de Histopatologia e Parasitologia, Instituto Multidisciplinar em Saúde, Campus Anísio Teixeira, Universidade \\ Federal da Bahia, Rua Rio de Contas, Quadra 17, 58, Bairro Candeias, 45029-094 Vitória da Conquista, BA, Brasil \\ ${ }^{2}$ Instituto de Ciências Biomédicas II, Departamento de Microbiologia, Universidade de São Paulo, \\ Av. Professor Lineu Prestes, 1374, Cidade Universitária, 05508-000 São Paulo, SP, Brasil
}

Manuscript received on April 1, 2015; accepted for publication on June 15, 2015

\begin{abstract}
Ureaplasma diversum is an opportunistic pathogen associated with uterine inflammation, impaired embryo implantation, infertility, abortions, premature birth of calves and neonatal pneumonia in cattle. It has been suggested that the intra-uterine infection by Ureaplasma diversum can cause vascular changes that hinder the success of pregnancy. Thus, the aim of this study was to evaluate the changes of intrauterine site of $\mathrm{A} / \mathrm{J}$ mice in estrus or proestrus phase inoculated with Ureaplasma diversum. The infection was monitored at 24, 48 and 72 hours by the PCR methodology to detect the Ureaplasma in the inoculation site and the profile of circulating blood cells. Morphological changes, intensity of inflammation and the production of cytokines were compared. The infected mice showed local inflammation through the production of IFN- $\gamma$ and TNF- $\alpha$. Ureaplasma diversum infections in the reproductive tract of studied mice seemed to be associated with the production of pro-inflammatory cytokines in uterine parenchyma. The levels of TNF- $\alpha$ of infected mice were dependent on the bacterial load of inoculated Ureaplasma. Uterine experimental infections by Ureaplasma diversum have not been mentioned yet and herein we presented the first report of an intrauterine infection model in mice.
\end{abstract}

Key words: Mycoplasma, uterus, Ureaplasma, mice.

\section{INTRODUCTION}

Ureaplasmas are free-living microorganisms characterized by the absence of cell wall and are involved in reproductive disorders in humans and animals (Versalovic et al. 2011). They have a small genome characterized by limited biosynthetic capabilities (Glass et al. 2000). When they are

Correspondence to: Robson Amaro Augusto da Silva

E-mail: robson.amaro@gmail.com grown, the medium is alkalinized to become toxic to the cells. Although they may grow in axenic cultures, the Ureaplasmas exhibit affinity for mucosal epithelium in the respiratory and urogenital tract.

Ureaplasma diversum stands out among molicutes causing reproductive disorders in cattle (Viscardi 2014, Waites et al. 2012). In addition, few studies have been performed to understand their pathogenicity. Infertility, endometritis, abortions, 
embryo implantation difficulties and some diseases of the urogenital tract are the most common clinical manifestations in infected cows (Taylor-Robinson et al. 1967, Argue et al. 2013). The compounds generated from the urea hydrolysis, as ammonia, are toxic to local cells (Miller et al. 1994). Their adherence on the host cells, allows access to lipids, pyrimidines and purines (Gambarini et al. 2009).

The premature births in bovines may be strongly linked to the ureaplasmal phospholipid activity (Saada and Kahane 1988). It has been suggested that the intra-uterine infection by $U$. diversum induces the production of bacterial phospholipases with arachidonic acid biosynthesis. This could interfere in the prostaglandin release and function of the host cells (Smith et al. 1993). These data have been correlated with changes in vascular permeability and decidualization of the endometrium (Viscardi 2010).

The immune response to the infection induces the cells release of inflammatory mediators. The kinetics and inflammatory profile to a stimulus are determined by the host genetics as well as the type of microorganism and its pathogenicity (Knights et al. 2014). Cytokines such as tumor necrosis factor alpha (TNF- $\alpha$ ) and interferon gamma (IFN- $\gamma$ ) have been shown to be important for the control of bacterial infections (Wang et al. 2015). However, the gestational uterus is affected by these mediators and it is related to premature births (Chandiramani et al. 2012), and other pregnancy complications (Kumar et al. 2014).

Recent outbreaks and epidemiological studies predict that the incidence of animal diseases caused by molicutes may increase. This situation indicates the need to develop new approaches to prevent and treat infections caused by these pathogens (Maxwell et al. 2006). Nevertheless, there are no animal models to be performed for the better understanding of immune responses due to $U$. diversum infections. In this study we aimed to evaluate the uterine infection by $U$. diversum in a mice model.

\section{MATERIALS AND METHODS}

\section{ANIMALS}

Female mice A/J aged 8-10 weeks were obtained from Universidade Federal da Bahia. The animals were kept in facilities with controlled humidity, temperature and light with $12 \mathrm{~h}$ cycle light $/ 12 \mathrm{~h}$ dark conditions as well as water and food provided ad libitum. This study was approved by the Ethics Committee in Research of Universidade Federal da Bahia.

\section{U. diversum PREPARATION AND CULTURE}

$U$. diversum ATCC 49782 were cultured according to the Ruhnke and Rosendal procedures (Ruhnke and Rosendal 1994). The isolates were obtained from the collection of Mycoplasma Laboratory of Institute of Biomedical Sciences at University of São Paulo/Brazil. Cultures of $100 \mathrm{~mL}$ was initially centrifuged at $15,000 \mathrm{x}$ g for 25 minutes at $4^{\circ} \mathrm{C}$, pelleted and gently washed with $\mathrm{NaCl} 0.85 \%$. The final pellet was homogenized in $\mathrm{NaCl} 0.85 \%$ solution aliquoted in $1 \mathrm{~mL}$ vials. This inoculum was quantified in 96-well microplates for Determination of Color Changing Units-methodology (CCU/ml) as described by Kim et al. (1994).

\section{INTRA-UTERINE INFECTION}

The mice were selected for inoculation according to the estrus or proestrus phase. The high viscosity of the mucus and the vaginal $\mathrm{pH}$ facilitates the infection process. The mice were divided in four groups including the control of infection. The mice were inoculated with saline (control group) or with doses of $10^{4}, 10^{6}, 10^{8} \mathrm{CCU}$ of $U$. diversum (infected groups). The ureaplasmal inoculum was carried out with the aid of a sterile catheter inserted intravaginally until they reach the cervix simulating an ascending infection. One, 2 and 3 days after the 
infection, body fluids and tissues were sampled and analyzed.

\section{CYTOLOGICAL ANALYSIS}

After euthanasia, blood samples were collected and glass slides were stained with panoptic. Cells counting were performed in a Neubauer chamber. Subsequent vaginal lavages were conducted in situ by injecting and removing a volume of $200 \mu 1$ of sterile saline for 5 times. These samples were stored at $4^{\circ} \mathrm{C}$ and then centrifuged at $300 \mathrm{x}$ g for 10 minutes at $4^{\circ} \mathrm{C}$. The pellets were subjected to cytospin and panoptic staining. The cell counts of the blood and vaginal fluids were obtained by morphological criteria under light microscopy at 100x magnification.

\section{EVALUATION OF CYTOKINE PRODUCTION}

Cytokines were measured in the supernatant of uterine macerated. The uterus of the animals were weighed. The same amount of tissue was macerated in RPMI and subjected to centrifugation at 300 $\mathrm{x} g$ for 10 minutes at $4^{\circ} \mathrm{C}$. Cytokines IFN- $\gamma$, IL- 1 and TNF- $\alpha$ were determined in the supernatant of the samples through sandwich immunoenzimatic procedure, using the ELISA kit Ready-SetGo ${ }^{\circledR}$ (Bioscience) accordingly manufacturer's instructions. The standard curve was obtained and cytokine levels were determined by comparison with standard curves.

\section{HISTOPATHOLOGY}

Uterine tissue fragments were fixed in $10 \%$ formalin overnight and then transferred to $95 \%$ ethanol until be embedded in paraffin, sectioned and stained with hematoxylin and eosin (HE). The uterus tissues were analyzed for the infiltration of inflammatory cells.

DETECTION OF $U$. diversum

$U$. diversum was detected in samples of uterine and vaginal lavages of infected mice. The fragments of uterus were initially homogenized in RPMI microtubes and centrifuged at $300 \mathrm{x}$ $\mathrm{g}$ for 10 minutes at $4^{\circ} \mathrm{C}$. Supernatants of vaginal lavages and uterus tissues were subjected to DNA extraction by boiling method to detect $U$. diversum by polymerase chain reaction (PCR) methodology as described by Cardoso et al. (2000). The DNA of the $U$. divsersum ATCC was the positive control and the negative control was an aliquot of PCR mix. The PCR products were electrophoresed in $1.5 \%$ agarose gel, stained with ethidium bromide and visualized by UV light. The evidence of a PCR product with $216 \mathrm{bp}$ indicates the targeted DNA of $U$. diversum.

\section{STATISTICAL TREATMENT}

Statistical analysis was performed by multiple comparisons in the different experiments using the test non-parametric (one-way ANOVA) KruskalWallis. Statistical differences were considered significant when $\mathrm{p}<0.05$ using a confidence interval of $95 \%$. All analyzes were performed at GraphPad Prism 4.0 program (GraphPad Software, San Diego, CA, USA).

\section{RESULTS}

U. diversum INDUCES INFLAMMATION in situ MEDIATED BY CYTOKINES

The intra-uterine infection in the inoculated mice with $U$. diversum did not induce differences in blood cells when compared to the control group (Figure 1a). Furthermore, the absolute number of white cells had no change at doses of $10^{4}, 10^{6}$ or $10^{8} \mathrm{CCU}$ of $U$. diversum (Figure 1b). The profile of circulating cells was also similar to the control group for both polymorph and mononuclear cells (Figure 1c and 1d). These data indicate that $U$. diversum, in this model of infection, does not induce systemic neutrophilia. 

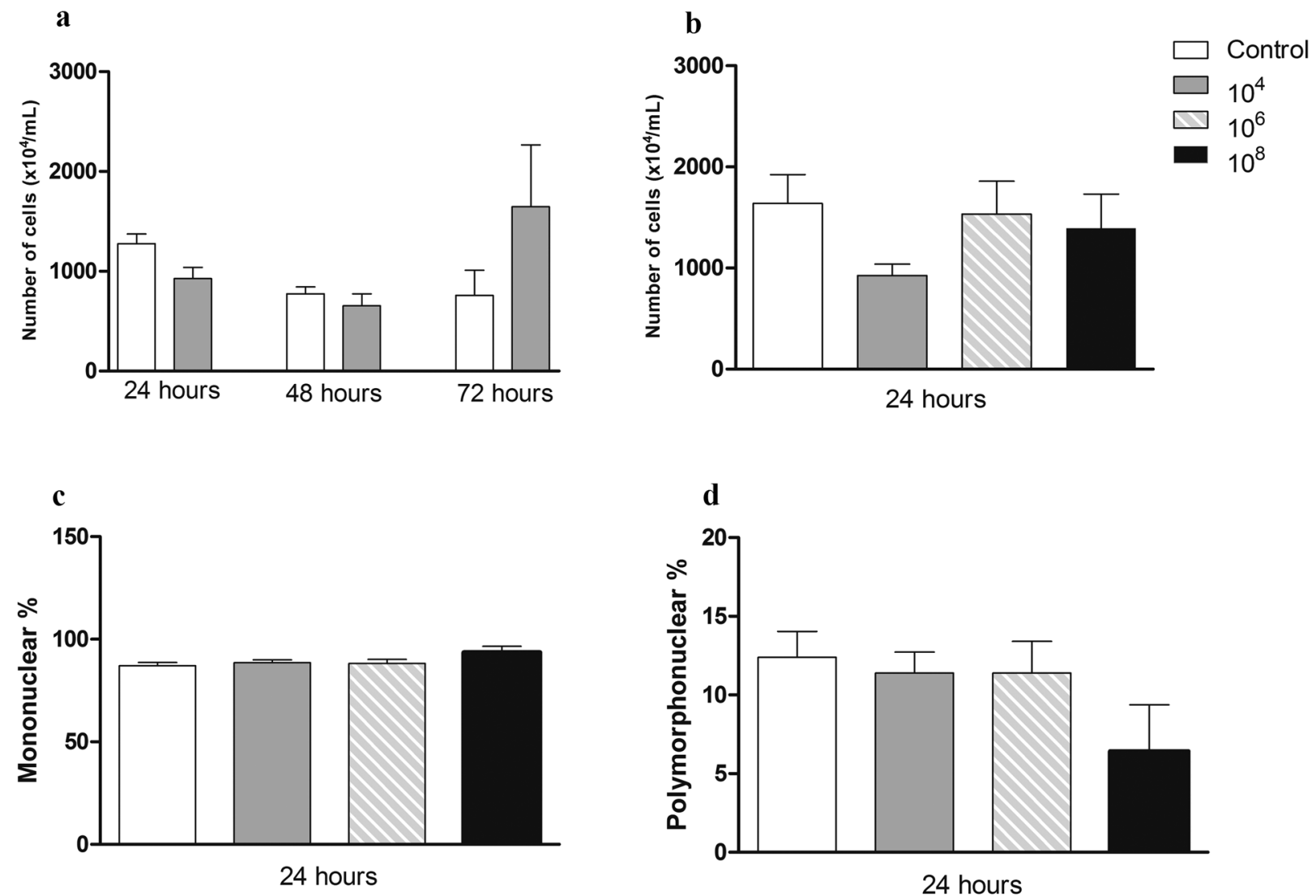

Figure 1 - Count of blood cells. A/J mice were infected with intrauterine doses of $10^{4}, 10^{6}$ or $10^{8}$ U. diversum. Twenty four, 48 and 72 hours after infection, the animals were euthanized and blood samples were collected. Immediately after euthanasia, the total number of cells was determined in Neubauer chamber. For the differential counts, slides were stained with panotic and counting was performed with a light microscope using 1000x magnification. Cells were characterized and differentiated, and the percentage was estimated according the total number of cells. (a) and (b) total number of leukocytes. (c) Percentage of mononuclear. (d) percentage of polymorphonuclear cells. n 3-5.

Changes in tissue morphology as a consequence of the inflammatory response in the inoculated site of mice were not detected (Figure 2a). Infected and non-infected mice presented neutrophils and lymphocytes in the endometrial tissue as well as presented in natural cell infiltration. The same was observed in vaginal lavages seeing that females in the control group showed a natural infiltration (Figure 2b). The morphology of the uterus, tubes and ovaries were preserved at all experimental time points (data not shown). The ureaplasmal targeted DNA was detected by PCR in uterus tissues at all experimental time points of infection inoculated with the lowest inoculum (Figure 2c). However, $U$. diversum DNA was not detected in vaginal lavages of infected and non-infected mice.

The production of pro-inflammatory cytokines such as IL-1 $\beta$, TNF- $\alpha$ and IFN- $\gamma$ in the uterus were evaluated by ELISA. The studied ureaplasmal infection markedly induced the production of TNF- $\alpha$ in the infection site (Figure 3a). This cytokine production seemed to be dependent of the inoculum since their levels increased proportionally to the injected ureaplasmal CCU (Figure 3b). However, no significant IL-1 $\beta$ production was observed in the studied model of infection (Figure 3c). In the uterus the levels of IFN- $\gamma$ increased when $10^{6} \mathrm{CCU}$ of $U$. diversum was inoculated (Figure 3d). 


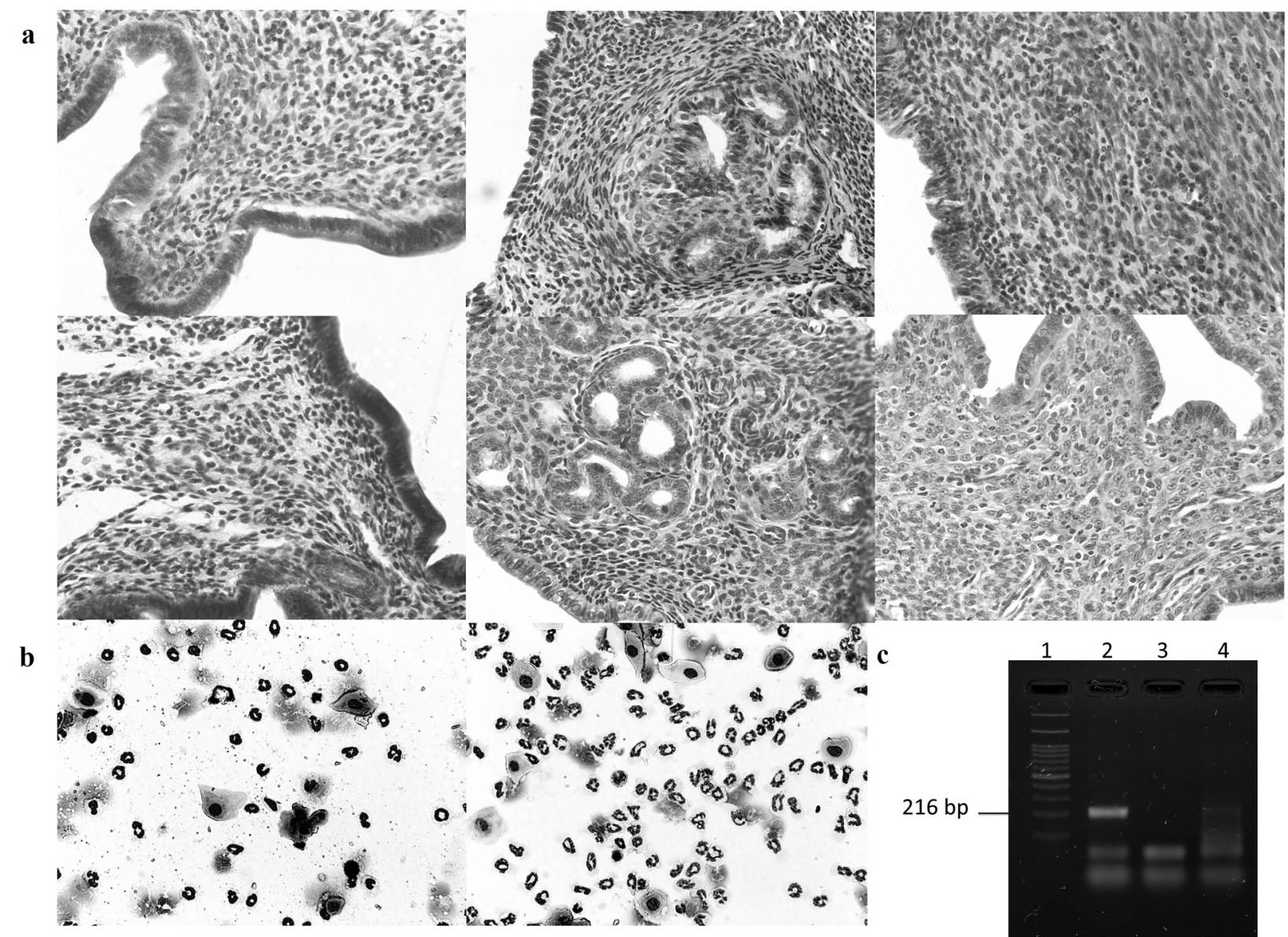

Figure 2 - Cytological analysis and detection of $\boldsymbol{U}$. diversum. A/J mice were infected with $10^{4} \mathrm{CCU}$ of $U$. diversum intrauterine route. (a) Twenty four, 48 and 78 hours after infection the animals had uterus fixed in $10 \%$ formalin. The slides were prepared and subsequently stained with hematoxylin and eosin. Photomicrographies upper and lower show control and infected animals 24 , 48 and 72 hours respectively, 400X (b) Vaginal lavage of control and infected mice 24 hours after infection respectively, 400X magnification. (c) U. diversum detection by PCR. Animals infected by U. diversum had genomic DNA extracted from uterine tissue and amplified by PCR. The products of PCR amplification using the primers UD3 (5'-AAT GTC GGC TCG CTT ATG AG-3') and UD4 (5'-CCT GTC ATA TTG TTA ACC TCC GC-3') were analyzed by agarose gel electrophoresis. The presence of a 216 bp DNA fragment indicated the specific detection of $U$. diversum. 1. Lader; 2. Positive control; 3. Negative control; 4 . Infected $10^{4}$ after 72 hours.

\section{DISCUSSION}

The presence of $U$. diversum in the reproductive tract of cattle hosts is associated with spontaneous abortion or premature birth of calves (Kreplin and Maitland 1989). Genetically defined animal models will be essential to understand the interactions in relation parasite / host that contribute to disease severity (Zhu et al. 2011). In the present study, infection of the reproductive tract of mice with $U$. diversum was associated with a local uterine inflammation. The results showed that the effects of infection depend on the bacterial load, and TNF- $\alpha$ and IFN- $\gamma$ were the most involved cytokines in the inflammatory response in this model. In contrast, the infection was not able to induce a systemic response associated with the preservation of the uterus morphology.

For a long time the pathogenicity of Ureaplasma was discussed. The etiologic role of Ureaplasmas was confused by the isolation of this mycoplasma 

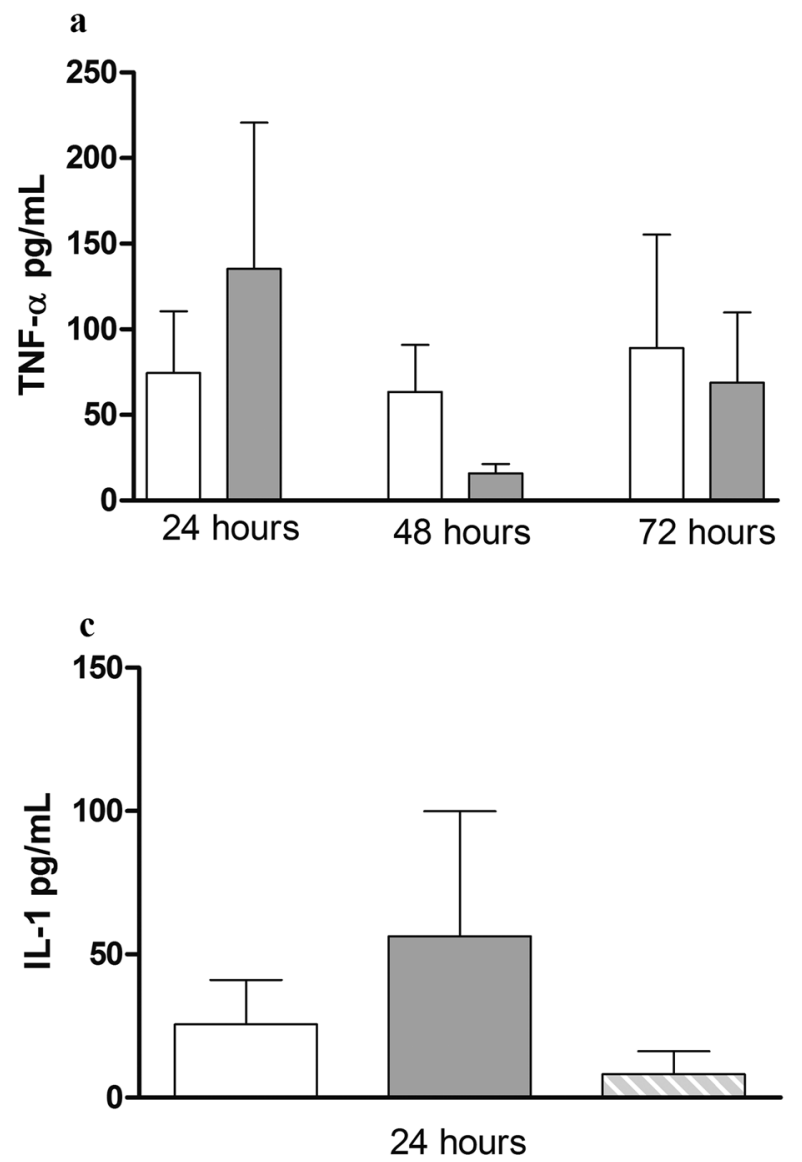

b

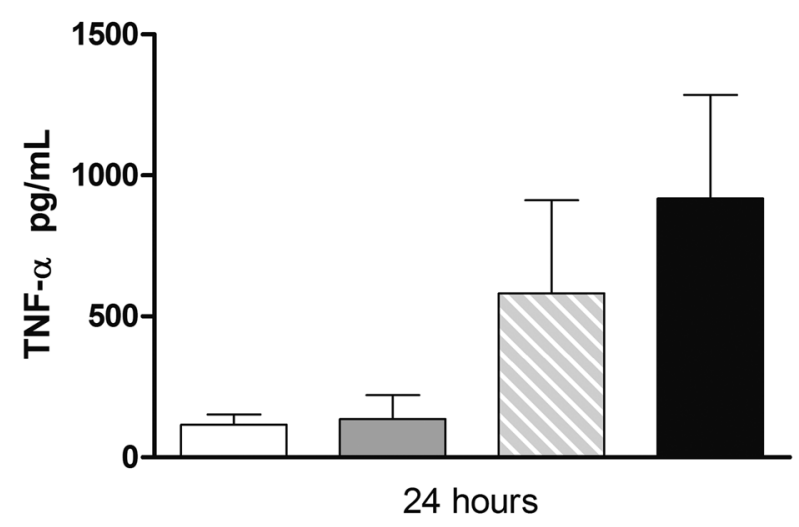

d

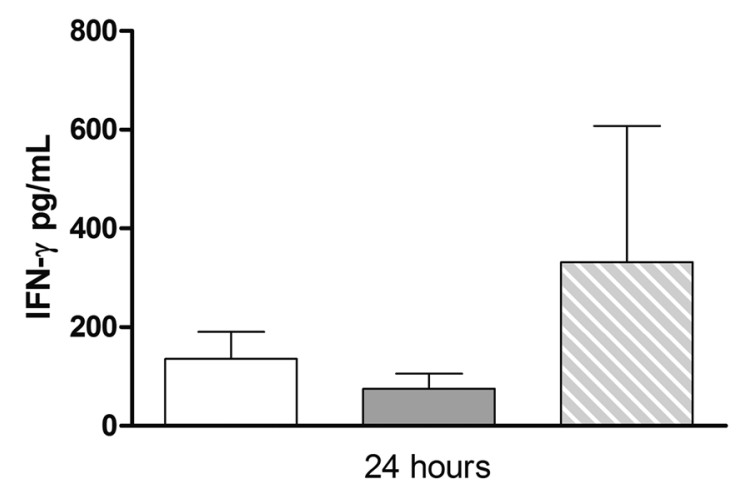

Figure 3 - Effect of $\boldsymbol{U}$. diversum intrauterine infections in $\mathbf{A} / \mathbf{J}$ mice. A/J mice were infected intravaginally by $U$. diversum and euthanized 24, 48 or 72 hours after infection. The uterus was macerated in medium RPMI centrifuged and the supernatant were used for measurement of cytokines (IL-1 $\beta$, TNF- $\alpha$, IFN- $\gamma$ ) by ELISA. a. TNF- $\alpha$ twenty four, 48 and 72 hours. b. TNF- $\alpha$ twenty four hours. c. IL-1 twenty four hours. d. IFN- $\gamma$ twenty four- hours. n 3-5.

in apparently healthy cows (Thomas et al. 2002). Since the intra-uterine infection was not able to induce a leukocytosis even with the increased bacterial load, it suggests that $U$. diversum is an opportunistic pathogen of low virulence to induce a systemic response. However, the damage to the host may be related to the site of infection. Studies show that colonization of the reproductive tract is commonly associated with infertility, abortions, premature births and lung injury in neonates (Ruhnke et al. 1984, Murray 1991, Buzinhani et al. 2011). In other mycoplasma species, such as $U$. urealyticum, was observed that the presence of bacteria in the respiratory tract of infants stimulates an increasing total number of white blood cells
(Viscardi et al. 2002). However, the observed leukocytosis is associated with low immunity (Tegtmeier et al. 1999, Ohlsson et al. 1993, Honma et al. 2007). Von Chamier et al. (2012) reported that intra-uterine experimental infection in mice with $U$. parvum was able to induce sepsis with severe fetal inflammatory response. Thus, the host immune response could be a determinant factor in the severity of disease, since immunosuppressed animals are more likely to develop a systemic response (Famuyide et al. 2009, Peng et al. 2013).

In this study, the local cell infiltrate observed in both infected and control groups was not related to infection by $U$. diversum. The presence of inflammatory cells in uterus tissue and in vaginal 
lavages seems to be directly related to the estrous cycle in female. During metaestrus, a number of neutrophils infiltrate the vaginal cavity (Kobayashi 2013, Sasaki et al. 2009). Neutrophil infiltration into the vagina is critical in maintaining the cycle by controlling the levels of steroid hormones and angiogenesis via production of chemoattractants (Jiemtaweeboon et al. 2011). In this model, the presence of mycoplasma and leukocytes did not affect the histological characteristics of the uterine tissue. In vitro studies with Mycoplasma genitalium demonstrated alterations after 72 hours of inoculation. Ultra-structural changes were observed with reduction of microvilli in the endometrial epithelial cells (McGowin et al. 2013). However, for Ureaplasma ssp., histological alterations are mostly related to chronic fetal infections (Robinson et al. 2013) or other body sites as lung (Viscardi et al. 2002). Although this study did not assess the progression of later periods, this model of infection by $U$. diversum does not induce an acute inflammatory response in healthy animals.

It is known that an increased influx of phagocytic cells to the site of infection is directly related to bacterial clearance. Neutrophil depletion studies have shown that the absence of recruitment of these cells is the main cause for the increased bacterial load (Segal 2005). These observations are consistent with results from our previous studies where was observed that the control of pulmonary infection by $U$. diversum was co-related to an influx of neutrophils into the lung (J.R. Silva et al., unpublished data). In this way, absence of recruitment of polymorphnuclear cells to the site of infection could be related to the colonization of the tissue.

It has been reported that in asymptomatic infections, $U$. parvum causes a change in the function of epithelial host cell characterized by the absence of inflammatory infiltrate (Reyes et al. 2009, Allam et al. 2011). These changes are associated with significant modifications in actin-binding proteins that regulate cell motility, differentiation, apoptosis, and inflammation that supports the colonization of microorganisms (Gloerich et al. 2010). Evasion mechanisms of the immune response are characterized for Ureaplasma ssp., but specifically for $U$. diversum was not reported. These species might share genes, virulence factors and evasion mechanisms of the immune response, preventing the control of bacterial load.

$U$. diversum was detected in macerated uterus even at the lowest dose 72 hours after infection. However, there was not observed positive samples in vaginal lavages. $U$. diversum is capable of adhesion to tissue and it has been reported the rapid invasion of Hep-2 cell being located in the perinuclear region of the cell (Marques et al. 2010). Thus, the absence of DNA found could be associated to the accession to the tissue or an intracell infection in the endometrium.

The profiles of the inflammatory response observed in the uterus were directly dependent on the administered dose of infection. The results presented here demonstrate that the bacterial load has been the major factor in the increased levels of pro-inflammatory mediators in the infection site. Higher bacterial load of $U$. diversum has been associated with more severe clinical conditions (Marques et al.2013). Infected animals respond with increased levels of TNF- $\alpha$ and IFN- $\gamma$ production. In vitro studies demonstrated that $U$. diversum was able to induce murine macrophages to produce TNF- $\alpha$ in a dose dependent way (ChelmonskaSoyta et al. 1994). Furthermore, U. urealyticum stimulates the release of TNF- $\alpha$ by macrophages and monocytes from human umbilical cord blood (Manimtim et al. 2001). Infections with $U$. diversum in the reproductive tract may, at first, not stimulate recruitment of cells to the site. However, the pro-inflammatory cytokines can be detrimental to uterine pregnancies (Rogerson et al. 2007).

Immunological alterations occur in the gestational environment to promote maternal 
tolerance to alloantigen and to ensure the survival of the developing fetus. This can change the host response against pathogens (Miller et al. 2009). Responses to infectious diseases endanger the health of the fetus, implantation, causing spontaneous abortion, fetal reabsorption or preterm births (Marenzoni et al. 2013). It has been reported that elevated levels of pro-inflammatory cytokines, including TNF- $\alpha$, are present in most premature births (Marchioni and Lichtenstein 2013). Moreover, the effects of cytotoxic T cells and IFN- $\gamma$, TNF- $\alpha$ and IL - 2 could lead to placental damage and fetal death mediated by destruction of syncytium-trophoblasts. TNF is reported as an embryotoxic cytokine, inducing trophoblast apoptosis via TNF receptors, especially if the cytokine is released by monocytes in direct contact with trophoblast (Haimovici et al. 1991, Yui et al. 1996, Chan and Guilbert 2005).

The presence of $U$. urealyticum in the reproductive tract during pregnancy also has been associated with premature rupture of fetal membranes mediated by TNF- $\alpha$ and IL- 6 response. These cytokines stimulate the secretion of other mediators, including prostaglandin $\mathrm{E}_{2}$ and matrix metalloproteinases, which participate in the weakening of the fetal membranes and consequent disruption (Estrada-Gutierrez et al. 2010).

Limitations of this study include I) study of the evolution of the infection at advanced periods for assessment of the inflammatory response and II) identification of neutrophils that respond against $U$. diversum to differentiate those and the ones naturally present due to the estrous cycle. Despite these limitations, this study provides data about the behavior of female hosts against infections of the reproductive tract by $U$. diversum. Although this study cannot conclude that the similar effects observed with intra-uterine infections caused by other species of mycoplasma, this may occur with $U$. diversum; it is worth mentioning the importance of the immune status of the host in disease pathogenesis.
Taken together, the data presented here suggests that the pathogenesis of $U$. diversum forward to infections of the reproductive tract may be significantly related to immune status of the host. Inflammatory mediators stimulated by infection with $U$. diversum may be the causal link between intrauterine infection and tissue injury related to abortions. It is possible that high bacterial loads present in gestational uterus contribute to inflammation via pro-inflammatory mediators, thus hampering the course of pregnancy. This is the first report of an intra-uterine infection in mice induced by $U$. diversum, however, further studies are needed to investigate the role of bacteria in low immunological competence.

\section{RESUMO}

Ureaplasma diversum é um patógeno oportunista associado com inflamação uterina, implantação do embrião prejudicada, infertilidade, abortos, nascimento prematuro de bezerros e pneumonia neonatal em gado. Tem sido sugerido que infecções causadas por Ureaplasma diversum podem causar alterações vasculares que impedem o sucesso da gravidez. Portanto, o objetivo desse estudo foi avaliar as alterações intrauterinas em camundongos $\mathrm{A} / \mathrm{J}$ na fase de estro ou proestro inoculados com Ureaplasma diversum. A infecção foi avaliada após 24,48 e 72 horas pela metodologia de PCR para detectar Ureaplasma no sítio de inoculação e o perfil de células sanguíneas circulantes. Alterações morfológicas, intensidade da inflamação e a produção de citocinas foram comparadas. Os camundongos infectados mostraram inflamação local pela produção de IFN- $\gamma$ e TNF- $\alpha$. Infecções por Ureaplasma diversum no trato reprodutivo dos camundongos estudados mostraram estar associadas com a produção de citocinas pró-inflamatórias no parênquima uterino. As concentrações de TNF- $\alpha$ nos camundongos infectados foram dependentes da carga bacteriana de Ureaplasma inoculado. Infecções uterinas experimentais por Ureaplasma diversum ainda não foram descritas e aqui nós apresentamos o primeiro relato de um modelo de infecção intrauterina em camundongos.

Palavras-chave: Micoplasma, útero, Ureaplasma, camundongos. 


\section{REFERENCES}

Allam AB, Alvarez S, Brown MB AND Reyes L. 2011. Ureaplasma parvum infection alters filamin A dynamics in host cells. BMC Infect Dis 20: 1-13.

Argue B, Chousalkar KK And ChenOweth PJ. 2013. Presence of Ureaplasma diversum in the Australian cattle population. Aust Vet J 91: 99-101.

BUZINHANI M, YAMAGUTI M, OLIVEIRA RC, CORTEZ BA, MARQUES LM, MACHADO-SANTELLI GM, ASSUMPÇÃO MEO AND TIMENETSKY J. 2011. Invasion of Ureaplasma diversum in bovine spermatozoids. BMC Res Notes 4: 1-8.

CARdoso MV, Blanchard A, Ferris S, VERlengia R, TIMENETSKY J AND CUNHA RAF. 2000. Detection of Ureaplasma diversum in cattle using a newly developed PCR-based detection assay. Vet Microbiol 72: 241-250.

CHAN G AND GUILBERT LJ. 2005. Enhanced monocyte binding to human cytomegalovirus-infected syncytiotrophoblast results in increased apoptosis via the release of tumour necrosis factor alpha. J Pathol 207: 462-470.

Chandiramani M, SEED PT, ORsi NM, EKBote UV, BENNETT PR, SHENNAN AH AND TRIBE RM. 2012. Limited relationship between cervico-vaginal fluid cytokine profiles and cervical shortening in women at high risk of spontaneous preterm birth. PLoS One 7: e52412.

CHELMONSKA-SoytA A, Miller RB, RUhNKE L AND ROSENDAL S. 1994. Activation of murine macrophages and lymphocytes by Ureaplasma diversum. Can J Vet Res 58: $275-280$.

EstradA-GUTIERREZ G, GOMEZ-LOPEZ N, ZAGAClAVELLINA V, GIONO-CEREZO S, ESPEJEL-NuÑEZ A, GONZALEZ-JIMENEZ MA, ESPINO Y SOSA S, OLSON DM AND VADILLO-ORTEGA F. 2010. Interaction between pathogenic bacteria and intrauterine leukocytes triggers alternative molecular signaling cascades leading to labor in women. Infect Immun 78: 4792-4799.

FAMUYide ME, HASDAY JD, CARTER HC, CHESKo KL, HE JR AND VISCARDI RM. 2009. Surfactant Protein-A Limits Ureaplasma-Mediated Lung Inflammation in a Murine Pneumonia Model. Pediatr Res Nature 66: 162-167.

GAMBARINI ML, KUNZ TL, OLIVEIRA FILHO BD, PORTO RN, OLIVEIRA CM, BRITO WM AND VIU MA. 2009. Granular Vulvovaginitis Syndrome in Nelore pubertal and post pubertal replacement heifers under tropical conditions: role of Mycoplasma spp., Ureaplasma diversum and BHV1. Trop Anim Health Pro 41: 1421-1426.

GLASS JI, LEFKOWITZ EJ, GLASS JS, HEINER CR, CHEN EY AND CASSELL GH. 2000. The complete sequence of the mucosal pathogen Ureaplasma urealyticum. Nature 407: 757-761.

GLOERICH M ET AL. 2010. Spatial regulation of cyclic AMPEpac1 signaling in cell adhesion by ERM proteins. Mol Cell Biol 30: 5421-5431.
HAIMOVICI F, HiLl JA AND ANDERSON DJ. 1991. The effects of soluble products of activated lymphocytes and macrophages on blastocyst implantation events in vitro. Biol Reprod 44: 69-75.

HONMA Y, YADA Y, TAKAHASHI N, MOMOI MY AND NAKAMURA Y. 2007. Certain type of chronic lung disease of newborns is associated with Ureaplasma urealyticum infection in utero. Pediatr Int 49: 479-484.

JiemtaWEeboon S, SHirasuna K, NitTA A, Kobayashi A, Schuberth H, Shimizu T AND Miyamoto A. 2011. Evidence that polymorphonuclear neutrophils infiltrate into the developing corpus luteum and promote angiogenesis with interleukin- 8 in the cow. Reprod Biol Endocrinol 9: 1-10.

KIM JJ, QUINN PA AND FORTIER MA. 1994. Ureaplasma diversum infection in vitro alters prostaglandin $\mathrm{E}_{2}$ and prostaglandin $\mathrm{F}_{2}$ a production by bovine endometrial cells without affecting cell viability. Infect Immun 62: 15281533.

KNIGHTS D ET AL. 2014. Complex host genetics influence the microbiome in inflammatory bowel disease. Genome Med 6: 107.

KOBAYASHI Y. 2013. The novel roles of neutrophils via opioid peptides: regulation of the estrous cycle and pain. Arch Immunol Ther Exp 61: 187-191.

KREPLIN CM AND MAITLAND VF. 1989. Abortion due to Ureaplasma diversum. Can Vet J 30: 435.

Kumar A, Begum N, Prasad S, LAmba AK, Verma M, AGARWAL S AND SHARMA S. 2014. Role of cytokines in development of pre-eclampsia associated with periodontal disease - cohort study. J Clin Periodontol 41: 357-365.

MANIMTIM WM, HASDAY JD, HESTER L, FAIRCHILD KD, LOVCHIK JC AND VISCARDI RM. 2001. Ureaplasma urealyticum modulates endotoxin-induced cytokine release by human monocytes derived from preterm and term newborns and adults. Infect Immun 69: 3906-3915.

MARCHIONI RM AND LiCHTENSTEIN GR. 2013. Tumor necrosis factor- $\alpha$ inhibitor therapy and fetal risk: a systematic literature review. World J Gastroenterol 19: 2591-2602.

MAREnZONi ML, BIETTA A, LEPRi E, CASAGRANDE PP, Cordioli P, CAnelli E, Stefanetti V, Coletti M, TIMONEY PJ AND PASSAMONTI F. 2013. Role of equine herpesviruses as co-infecting agents in cases of abortion, placental disease and neonatal foal mortality. Vet Res Commun 37: 311-317.

MARques LM, AMORIM AT, MARTINS HB, REZENDE IS, BARBosA MS, LOBÃO TN, CAMPOS GB AND TIMENETSKY J. 2013. A quantitative TaqMan PCR assay for the detection of Ureaplasma diversum. Vet Microbiol 31: 394-395.

MARQUES LM ET AL. 2010. Invasion of Ureaplasma diversum in Hep-2 cells. BMC Microbiol 10: 83. 
MAXWELl NC, DAVIES PL AND KoTECHA S. 2006. Antenatal infection and inflammation: what's new? Curr Opin Infect Dis 19: 253-258.

MCGOWIN CL, RADTKE AL, ABRAHAM K, MARTIN DH AND HERBST-KRALOVETZ M. 2013. Mycoplasma genitalium infection activates cellular host defense and inflammation pathways in a 3-dimensional human endocervical epithelial cell model. J Infect Dis 207: 1857-1868.

Miller CM, BOULTER NR, IKIN RJ AND SMITH NC. 2009. The immunobiology of the innate response to Toxoplasma gondii. Int J Parasitol 39: 23-39.

Miller RB, CJELMONSKA-SOYTA A, SMits B, Foster R AND ROSENDAL S. 1994. Ureaplasma diversum as a cause of reproductive disease in cattle. Vet Clin North Am Food Anim Pract 10: 479-490.

MURRAY RD. 1991. Concurrent conjunctivitis and placentitis in aborted bovine fetuses. Zentralbl Veterinarmed A 38: 660-667.

OHLSSON A, WANG E AND VEARnCOMBE M. 1993. Leukocyte counts and colonization with Ureaplasma urealyticum in preterm neonates. Clin Infect Dis 17: 144147.

Peng Y, WANG Y, HANG S AND ZHU W. 2013. Microbial diversity in uterus of healthy and metritic postpartum Holstein dairy cows. Folia Microbiol 58: 593-600.

REYES L, REINHARD M AND BROWN MB. 2009. Different inflammatory responses are associated with Ureaplasma parvum-induced UTI and urolith formation. BMC Infect Dis 9: 9.

ROBINSON JW ET AL. 2013. Ureaplasma parvum serovar 3 multiple banded antigen size variation after chronic intraamniotic infection/colonization. PLoS One 8: e62746.

ROGERSON SJ, HVIID L, DUFFY PE, LEKE RF AND TAYLOR DW. 2007. Malaria in pregnancy: pathogenesis and immunity. Lancet Infect Dis 7: 105-117.

RuhNKe HL, PALMER NC, DOIG PA AND Miller RB. 1984. Bovine abortion and neonatal death associated with Ureaplasma diversum. Theriogenol 2: 295-301.

RUHNKE HL AND ROSENDAL S. 1994. Useful protocols for diagnosis of animal mycoplasmas. In: Mycoplasmosis in Animals: Laboratory Diagnosis. Edited by Whitford HW, Rosenbusch RF, Lauerman LH. Iowa, Iowa State University Press, p. 141-144.

SAADA AB AND KAHANE I. 1988. Purification and characterization of urease from Ureaplasma urealyticum. Zentralbl Bakteriol Mikrobiol Hyg A 269: 160-167.

SASAKI S, NAGATA K AND KOBAYASHI Y. 2009. Regulation of the estrous cycle by neutrophil infiltration into the vagina. Biochem Biophys Res Commun 382: 35-40.

SEGAL AW. 2005. How neutrophils kill microbes. Annu Rev Immunol 23: 197-223.
SMITH DG, RUSSELl WC, INGLEDEW WJ AND THIRKELL D. 1993. Hydrolysis of urea by Ureaplasma urealyticum generates a transmembrane potential with resultant ATP synthesis. J Bacteriol 175: 3253-3258.

TAYLOR-ROBINSON D, HAIG DA AND WILLIAMS MH. 1967. Bovine T-strain mycoplasma. Ann N Y Acad Sci 143: $517-$ 518.

TegtMeier C, UtTenthal A, FriIs NF, Jensen NE AND JENSEN HE. 1999. Pathological and microbiological studies on pneumonic lungs from Danish calves. Zentralbl Veterinarmed B 46: 693-700.

Thomas A, BALl H, DizIER I, Trolin A, BELl C, MAINIL J AND LINDEN A. 2002. Isolation of mycoplasma species from the lower respiratory tract of healthy cattle and cattle with respiratory disease in Belgium. Vet Rec 151: 472-476.

Versalovic J, CARroll KC, FunKe G, Jorgensen JH, LANDRY ML AND WARNOCK DW. 2011. Manual of Clinical Microbiology. $10^{\text {th }}$ ed., ASM Press, Washington, DC.

VISCARDI RM. 2010. Ureaplasma species: role in diseases of prematurity. Clin Perinatol 37: 393-409.

VISCARDI RM. 2014. Ureaplasma species: role in neonatal morbidities and outcomes. Arch Dis Child 99: F87-F92.

VisCARDi RM, KAPLAN J, LOVCHIK JC, HE JR, HESTER L, RAO S AND HASDAY JD. 2002. Characterization of a murine model of Ureaplasma urealyticum pneumonia. Infect Immun 70: 5721-5729.

VON CHAMIER M, ALLAM A, BROWN MB, REINHARD MK AND REYES L. 2012. Host genetic background impacts disease outcome during intrauterine infection with Ureaplasma parvum. PLoS One 7: e44047.

WAITES KB, XIAO L, PARALANOV V, ViscARDI RM AND GLASS JI. 2012. Molecular methods for the detection of Mycoplasma and Ureaplasma infections in humans: a paper from the 2011 William Beaumont Bospital Symposium on Molecular Pathology. J Mol Diagn 14: 437-450.

WANG X, ZHANG J, LIANG J, ZHANG Y, TENG X, YUAN X AND FAN X. 2015. Protection against Mycobacterium tuberculosis Infection Offered by a New Multistage Subunit Vaccine Correlates with Increased Number of IFN- $\gamma+$ IL-2+ CD4+ and IFN- $\gamma+$ CD8 + T Cells. PLoS One 10: e0122560.

Yui J, HEMMINGS D, GARCIA-LlORET M AND GUILBERT LJ. 1996. Expression of the human p55 and p75 tumor necrosis factor receptors in primary villous trophoblasts and their role in cytotoxic signal transduction. Biol Reprod 55: 400-409.

ZHU GX, LU C, CHEN CJ, FENG PY, MA H, LU RB AND YUAN YL. 2011. Pathogenicity of Ureaplasma urealyticum and Ureaplasma parvum in the lower genital tract of female BALB/c mice. Can J Microbiol 57: 987-992. 